\title{
Inventarisasi Jenis Teripang (Holothuroidea) pada Zona Intertidal di Perairan Pulau Ottouwe Wakatobi
}

\author{
La Aba*1, Rusliadi ${ }^{2}$ \\ 1,2Universitas Muhammadiyah Buton; \\ e-mail: *11 laabarazak1980@ gmail.com,
}

\begin{abstract}
Abstrak
Penelitian ini bertujuan untuk mengetahui jenis-jenis teripang (Holothuroidea) pada zona intertidal di Perairan Pulau Ottouwe Kabupaten Wakatobi Sulawesi Tenggara. Daerah yang menjadi tempat penelitian ini yaitu di Perairan Pulau Ottouwe Kabupaten Wakatobi Sulawesi Tenggara. Penelitian ini memiliki tiga tahapan yaitu tahapan persiapan, tahapan pengambilan sampel, dan tahapan identifikasi. Berdasarkan hasil penelitian yang telah dilakukan di zona intertidal Pulau Ottouwe maka dapat disimpulkan bahwa pada lokasi tersebut ditemukan 12 spsies dari 60 spesies yang ada di Indonesia. Teripang tersebut dari 1 famili yang terdapat pada titik pengamatan (garis transek) yaitu Holothuroidea yaitu Holothuria scabra, Holothuria atra, Holothuria fuscocinerea, Holothuria leucospilota, Holothuria pervicax, Holothuria sp.1, Holothuria sp.2, Holothuria sp.3, Holothuria sp.4, Holothuria sp.5, Bohadschia marmorata, bohadschia argus.
\end{abstract}

\section{Kata kunci Teripang (Holothuroidea), Zona intertidal, Pulau Ottouwe}

\section{PENDAHULUAN}

Zona intertidal merupakan zona perairan yang mengalami pasang-surut air laut. Zona ini memiliki faktor fisik maupun faktor kimia yang mendukung semua organism di dalamnya untuk dapat tumbuh dan berkembang dengan baik. Nyabakken (1988:35) mengemukakan bahwa zona intertidal adalah daerah pantai yang terletak antara pasang tinggi dan surut terendah, daerah ini mewakili peralihan dari kondisi lautan ke kondisi daratan. Zona ini luasnya sangat terbatas, tetapi banyak terdapat variasi faktor lingkungan yang besar dibandingkan dengan daerah lautan lainnya, karena itu keragaman organismenya sangat tinggi. Hal ini di karenakan berbagai macam habitat yang ada di dalamnya seperti terumbu karang dan padang lamun (Pribadi, 2017). Salah satu hewan yang terdapat di zona intertidal adalah hewan yang termasuk dalam anggota Echinodermata.

Anggota Echinodermata sangat penting dalam ekosistem laut dan bermanfaat sebagai salah satu komponen dalam rantai makanan, pemakan sampah organik dan hewan kecil lainnya. Dahuri (2003) menyatakan bahwa jenis-jenis Echinodermata dapat bersifat pemakan seston atau pemakan destritus, sehingga peranannya dalam suatu ekosistem untuk merombak sisa-sisa bahan organik yang tidak terpakai oleh spesies lain namun dapat dimanfaatkan oleh beberapa jenis Echinodermata. Disamping itu, spesies Echinodermata seperti teripang memiliki nilai ekonomi penting karena merupakan bahan pangan yang memiliki nilai gizi penting (Satria,2014).

Pulau Ottouwe merupakan salah satu daerah pesisir Kabupaten Wakatobi, memiliki keanekaragaman jenis biota laut khususnya anggota Echinodermata. Akan tetapi, data tentang keanekaragaman jenis biota laut pada beberapa daerah di Kepulauan Buton khususnya di Kabupaten Wakatobi belum memadai. Namun disisi lain, aktivitas pemanfaatan dan ekspolitasi jenis-jenis biota laut terutama yang memiliki nilai ekonomis tinggi seperti teripang (Holothuroidea) terus dilakukan sehingga kondisi ini akan mengancam kelestarian dari berbagai jenis biota tersebut. Oleh karena itu, penelitian tentang jenis-jenis teripang (Holothuroidea) di Pulau Ottouwe sangat penting dilakukan guna mendapatkan data ilmiah mengenai jenis-jenis teripang dan membantu dinas terkait dalam hal pengambilan kebijakan untuk pengelolaan, pemanfaatan dan pelestariaan teripang secara berkelanjutan. Dengan demikian peneliti tertarik untuk melakukan penelitian mengenai "Inventarisasi Jenis-Jenis Teripang (Holothuroidea) pada Zona Intertidal di Perairan Pulau Ottouwe Kabupaten Wakatobi.

\section{METODE PENELITIAN}

\subsection{Desain Penelitian}


Pengamatan dilakukan secara deskriptif kualitatif dengan menggunakan metode garis transek. Pengambilan sampel dilakukan didua stasiun yang berbeda. Setiap stasiun memiliki garis transek sepanjang 100 meter dan lebar 100 meter. Pengamatan dilakukan pada saat air laut surut terendah baik siang maupun malam hari.
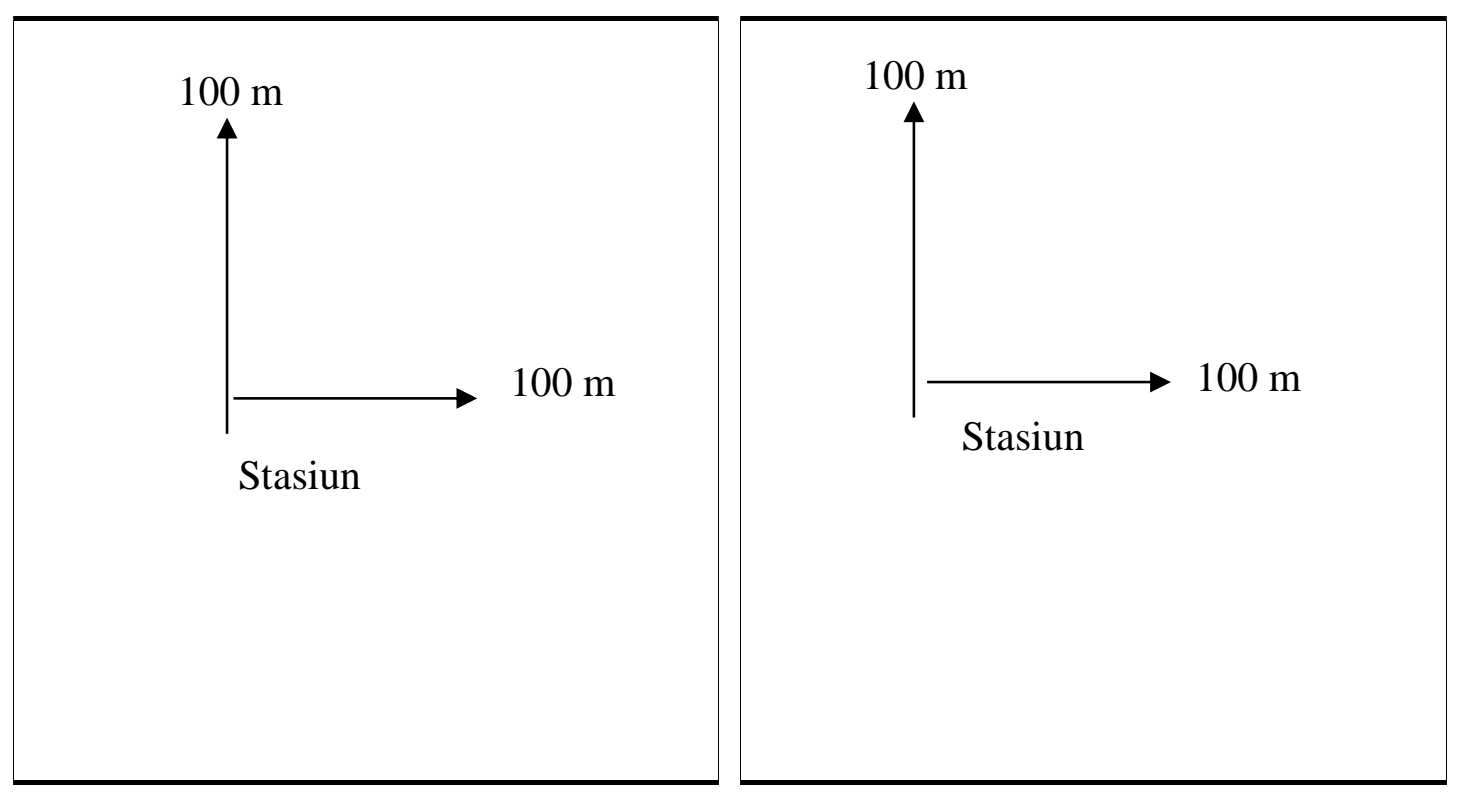

Keterangan:

Gambar 1. Stasiun Penelitian

$\longrightarrow$ : Garis transek

$100 \mathrm{~m}$ : Panjang transek

\subsection{Populasi dan Sampel Penelitian}

Populasi penelitian ini adalah jenis-jenis Teripang (Holothuroidea) yang terdapat di kawasan Perairan Pulau Ottouwe Kabupaten Wakatobi. Sampel penelitian ini adalah teripang (Holothuroidea) yang terdapat di setiap masing-masing stasiun.

\subsection{Instrumen Penelitian}

1. Alat

Alat yang digunakan dalam penelitian ini dapat dilihat pada table 2.1.

Tabel 1 Alat penelitian yang digunakan serta Fungsinya.

\begin{tabular}{|l|l|l|}
\hline No & \multicolumn{1}{|c|}{ Nama alat } & \multicolumn{1}{c|}{ Fungsinya } \\
\hline 1. & Kamera & dokumentasi sampel \\
\hline 2. & Alat tulis menulis & mencatat data hasil penelitian \\
\hline 3. & Gunting & alat pemotong \\
\hline 4. & Tali rafia & membuat plot \\
\hline 5. & Ember & Menyimpan sampel \\
\hline 6. & Kertas stirimin & pengalas sampel penelitian \\
\hline 7. & Buku Identifikasi & mengidentifikasi morfologi teripang \\
\hline 8. & Kertas lakmus & Untuk mengetahui keasaman \\
\hline 9. & Thermometer & Untuk mengukur suhu udara dan air laut \\
\hline 10. & Pinset & Untuk penjepit sampel dan kertas lakmus \\
\hline
\end{tabular}


https://jurnal.unsulbar.ac.id/index.php/saintifik

2. Bahan

Bahan yang digunakan dalam penelitian ini dapat dilihat pada tabel 2.2

Tabel 2 Bahan penelitian yang digunakan serta fungsinya.

\begin{tabular}{|l|l|l|}
\hline No & Nama bahan & \multicolumn{1}{c|}{ Fungsinya } \\
\hline 1. & Bintang laut (Asteroidea) & Sampel penelitian \\
\hline
\end{tabular}

\subsection{Prosedur Penelitian}

Daerah yang menjadi tempat penelitian ini yaitu di Perairan Pulau Ottouwe Kabupaten Wakatobi Sulawesi Tenggara. Penelitian ini memiliki tiga tahapan yaitu tahapan persiapan, tahapan pengambilan sampel, dan tahapan identifikasi. Tahap persiapan meliputi proses persiapan alat-alat yang akan digunakan dan titik lokasi sampel penelitian. Penentuan titik lokasi dilakukan dengan cara melakukan survei lokasi penelitian. Survei pendahuluan ini dilakukan mengetahui kondisi lokasi penelitian. Pengambilan sampel teripang (Holothuroidea) dilakukan dengan menjelajahi setiap stasiun. Sampel diperoleh difoto dengan menggunakan kamera digital sebagai bahan dokumentasi. Sampel yang diperoleh di dalam plot pada masing-masing diindetifikasi karakter morfologinya dengan menggunakan buku indetifikasi Zoologi Invertebrata, jurnal, dan skripsi. Proses Identifikasi dilakukan di Laboratorium Dasar IPA Universitas Muhammadiyah Buton.

\subsection{Teknik Analisis Data}

Data yang diperoleh dianalisis secara deskriptif. Sampel Teripang (Holothuroidea) yang diperoleh di Perairan Pulau Ottouwe Kabupaten Wakatobi dideskripsi berdasarkan ciri morfologinya. Dengan menggunakan buku identifikasi Pedoman Umum Identifikasi dan Monitoring Populasi Teripang (Didi dkk, 2015), Buku Identifikasi Zoology Invertebrata (Teori dan Praktek) (Rusyana), Jurnal dan Skripsi.

\section{HASIL DAN PEMBAHASAN}

\subsection{Hasil Penelitian}

\subsubsection{Karakteristik Habitat Perairan}

Kondisi substrat pada perairan Pulau Ottouwe terdiri dari pasir halus, berkarang hingga padang lamun yang cukup dominan, serta paparan karang pada daerah tubir dibatasi oleh karang yang sudah agak rusak. Pada beberapa lokasi penelitian dijumpai pasir berlumpur yang tidak begitu banyak.

\subsubsection{Parameter Lingkungan pada Zona Intertidal Perairan Pulau Ottouwe Kabupaten Wakatobi}

Tabel 3 Data Parameter Lingkungan

\begin{tabular}{|c|c|c|c|c|c|c|c|}
\hline \multirow{2}{*}{ No } & Parameter & \multicolumn{6}{|c|}{ Stasiun Penelitian } \\
\cline { 3 - 8 } & & \multicolumn{3}{|c|}{ Stasiun I } & \multicolumn{3}{c|}{ Stasiun II } \\
\hline 1 & Subtrat & Pasir & Karang & Lamun & Pasir & Karang & Lamun \\
\hline 2 & Suhu & $23^{\circ} \mathrm{C}$ & $26^{\circ} \mathrm{C}$ & $24^{\circ} \mathrm{C}$ & $23^{\circ} \mathrm{C}$ & $26^{\circ} \mathrm{C}$ & $24^{\circ} \mathrm{C}$ \\
\hline 3 & $\mathrm{pH}$ & 7 & 6 & 7 & 7 & 6 & 7 \\
\hline
\end{tabular}

Jenis subtrat yang dihuni oleh Ecinodermata khususnya Holothuroidea pada setiap stasiun penelitian ini berupa pasir, batu, pecahan karang, padang lamun, dan koloni karang. Hewan ini biasanya hidup melekat (sesil) pada subtrat. Menurut Yusron (2006), Holothuroidea dapat hidup menempati berbagai mikrohabitat seperti zona rataan terumbu, daerah pertumuhan alga, padang lamun, koloni karang hidup, karang mati serta beting karang (rubbles). Berdasarkan Tabel 3 terlihat bahwa suhu perairan di Perairan Pulau Ottouwe berkisar antara $23{ }^{\circ} \mathrm{C}-26{ }^{\circ} \mathrm{C}$, suhu tertinggi 
diperoleh pada pengambilan sampel di stasiun 1 dan II pada substrat berkarang yaitu $26^{\circ} \mathrm{C}$ dan suhu terendah pada pengambilan sampel di stasiun I dan II pada substrat berpasir yaitu $23^{\circ} \mathrm{C}$. Menurut Ikhsan N. (2014), suhu perairan Pulau Wanci berkisar $30-31^{\circ} \mathrm{C}$. Hal ini menunjukan kondisi suhu tidak stabil karena di pengaruhi oleh beberapa faktor, salah satu diantaranya seperti kondisi cuaca pada saat pelaksanaan penelitian di lapangan. Sutaman (1993), bahwa suhu air laut yang baik untuk kehidupan teripang berkisar antara $20^{\circ} \mathrm{C}-31^{\circ} \mathrm{C} . \mathrm{pH}$ pada kedua stasiun penelitian yaitu berkisar 6-7. Menurut Ikhsan N. (2014), menyatakan bahwa pH pada perairan Pulau Wanci berkisar 7-7,5. Menurut Effendi (2003) pH menggambarkan keberadaan ion hidrogen yang terdapat pada suatu perairan. $\mathrm{pH}$ perairan biasanya akan mengalami penurunan ketika suhu rendah akibat kurangnya intensitas matahari, sehingga proses fotosintesis oleh tumbuhan air akan berkurang. Jenis-jenis Teripang (Holothuroidea)

3.1.3 Berdasarkan hasil penelitian diketahui bahwa di Perairan Pulau Ottouwe Kabupaten Wakatobi terdapat 12 jenis teripang (Holothuroidea) yang terdiri dari 2 Genus diantaranya adalah:

Tabel 4 Jenis Teripang (Holothuroidea) di Perairan Pulau Ottouew Kabupaten Wakatobi Sulawesi Tenggara.

\begin{tabular}{|c|c|c|c|c|c|c|c|c|}
\hline \multirow[t]{3}{*}{ No } & \multirow[t]{3}{*}{ Spesies } & \multicolumn{6}{|c|}{ Stasiun Penelitian } & \multirow[t]{3}{*}{ Individu } \\
\hline & & \multicolumn{3}{|c|}{ Stasiun I } & \multicolumn{3}{|c|}{ Stasiun II } & \\
\hline & & Pasir & karang & Lamun & pasir & Karang & lamun & \\
\hline 1 & H. scabra & 2 & 1 & 4 & 4 & 1 & 3 & 15 \\
\hline 2 & H. atra & 2 & 1 & 3 & 4 & - & 3 & 13 \\
\hline 3 & H. fuscocinerea & 3 & 1 & 2 & 2 & 1 & 3 & 12 \\
\hline 4 & H. leucospilota & 2 & 2 & 1 & 1 & 1 & 5 & 12 \\
\hline 5 & B. vitiensis & 3 & - & 3 & 1 & 2 & 2 & 11 \\
\hline 6 & $B$, argus & 1 & 1 & 2 & 1 & & 4 & 9 \\
\hline 7 & H. pervicax & 2 & - & 1 & 1 & 1 & 2 & 7 \\
\hline 8 & H. sp. 1 & 1 & 2 & 1 & - & - & 2 & 6 \\
\hline 9 & H. sp. 2 & 1 & 1 & 1 & 2 & - & 1 & 6 \\
\hline 10 & H. sp. 3 & - & - & 2 & 1 & 1 & 2 & 6 \\
\hline 11 & H. sp. 4 & - & - & 1 & 1 & - & 1 & 3 \\
\hline 12 & H. sp. 5 & 1 & - & - & - & - & - & 2 \\
\hline & \multicolumn{7}{|c|}{ Jumlah } & 102 \\
\hline
\end{tabular}

\subsubsection{Deskripsi dan Klasifikasi Jenis-Jenis Teripang (Holothuroidea)}

a. Holothuria scabra
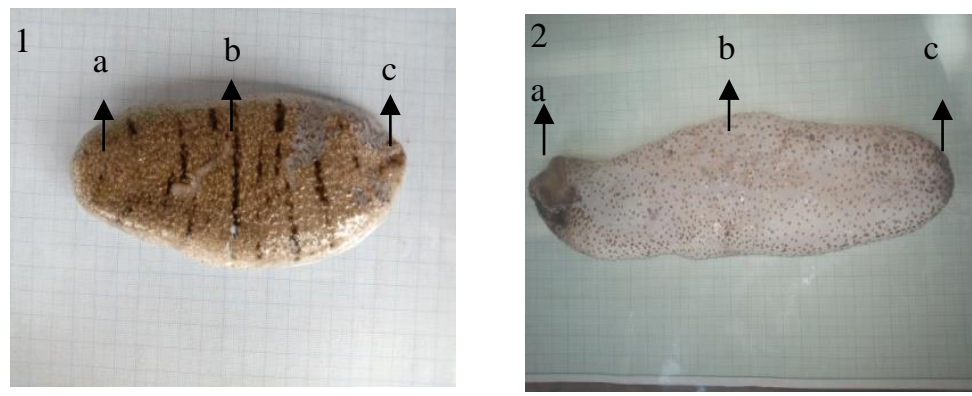

Gambar 2 Holothuria scabra: 1. Dorsal: a. Celah anus, b. Bar sekunder, c. Celah mulut. 2. ventral: a. Anterior, b.Spot, c Posterior

Klasifikasi (pengelompokan) Holothuria scabra dalam sistem taksonomi yaitu sebagai berikut:

Kingdom : Animalia

Filum : Echinodermata

Kelas : Holothuroidea 
Ordo : Aspidochirotida

Famili : Holothuriidae

Genus : Holothuria

Spesies : Holothuria scabra (Jaeger, 1935)

Teripang Pasir (Holothuria scabra) mempunyai bentuk tubuh bulat memanjang. Panjang tubuh $\pm 16 \mathrm{~cm}$ dan lebar tubuh $\pm 8 \mathrm{~cm}$. Pada bagian dorsal berwarna abu-abu sampai kehitaman dengan garis-garis melintang dan antara garisgaris itu terdapat warna putih. Warna bagian ventral kuning keputihan dengan bercak-bercak hitam kecil. Seluruh permukaan kulitnya kasar bila diraba. Teripang ini hidup soliter antara karang dan perairan yang memiliki substrat pasir halus serta ditumbuhi rumput laut.

\section{b. Holothuria atra}
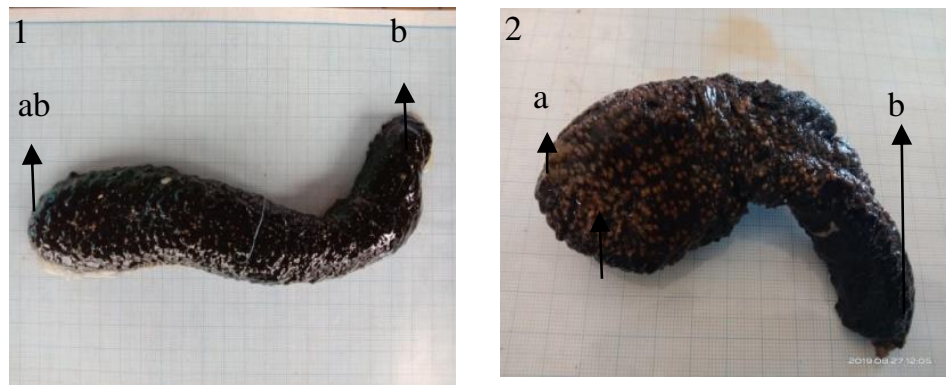

Gambar 3 Holothuria atra: 1. Dorsal: a. Celah anus, b. Celah mulut. 2. Ventral: a. Spot, b. Tentakel

Klasifikasi (pengelompokan) Holothuria atra dalam sistem taksonomi yaitu sebagai berikut:

Kingdom : Animalia

Filum : Echinodermata

Kelas : Holothuroidea

Ordo : Aspidochirotida

Famili : Holothuriidae

Genus : Holothuria

Spesies : Holothuria atra (Jaeger, 1957)

Teripang keling atau teripang darah (Holothuria atra) memiliki bentuk tubuh bulat memanjang seluruh permukaan tubuhnya berwarna hitam dan terdapat bintik-bintik berwarna halus serta memiliki tentakel berwarna kuning keputihan. Panjang tubuh $\pm 20 \mathrm{~cm}$ dan lebar tubuh $\pm 4 \mathrm{~cm}$. Teripang keling ini biasa hidup di daerah perairan berkarang dan berpasir serta ditumbuhi padang lamun

\section{c. Holothuria fuscocinerea}
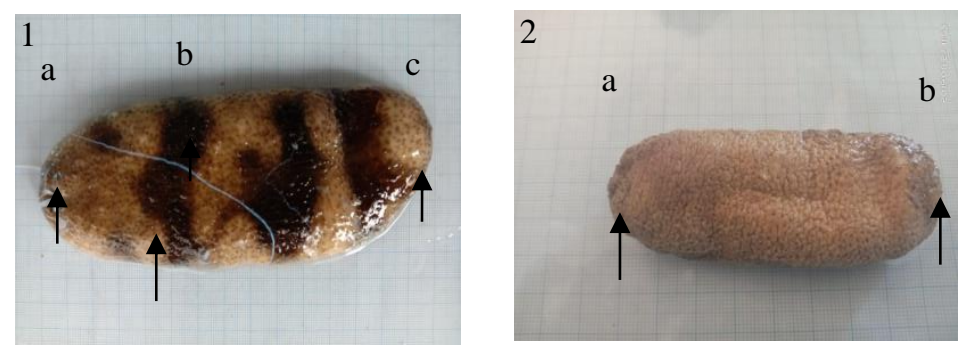

Gambar 4 Holothuria fuscocinerea: 1. Dorsal: a. Bar sekunder, b. Bar primer, c. spot. 2.Ventral: a. Celah anus, b. Celah mulut

Klasifikasi (pengelompokan) Holothuria fuscocinerea dalam sistem taksonomi yaitu sebagai berikut:

Kingdom : Animalia

Filum : Echinodermat

Kelas : Holothuroidea

Ordo : Aspidochirotida 
Famili : Holothuriidae

Genus : Holothuria

Spesies : Holothuria fuscocinerea (Jaeger, 1833)

Holothuria fuscocinerea hidup pada subtrat pasir dan pada lamun, memiliki panjang tubuh $\pm 15 \mathrm{~cm}$ dan lebar $\pm 8 \mathrm{~cm}$, warna tubuh coklat muda, serta memiliki bintik-bintik berwarna coklat kehitaman. Pada bagian dorsal terdapat garis bercorak kehitaman, mulut memiliki tentakel dan anus berwarna hitam. Pada bagian ventral berwarna putih. Teripang ini hidup di daerah berpasir dan berkarang serta di tumbuhi padang lamun. d. Holothuria leucospilota
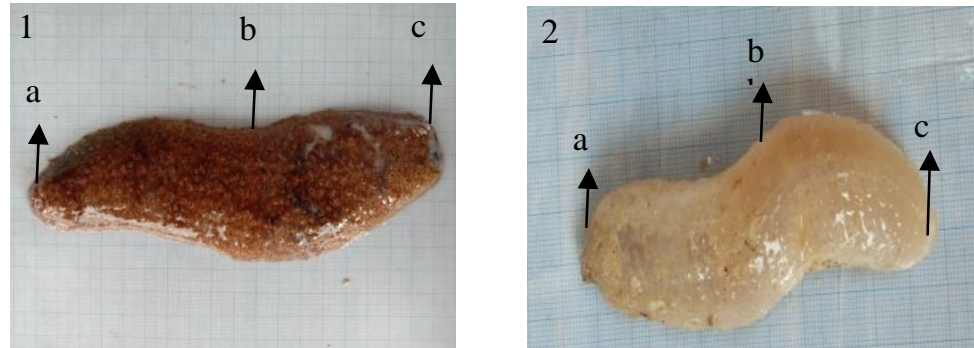

Gambar 5 Holothuria leucospilota: 1. Dorsal: a. Celah anus, b. spot, c. Celah mulut. 2. Ventral: a. Anterior, b. Spot, c. Posterior.

Klasifikasi (pengelompokan) Holothuria leucospilota dalam sistem taksonomi yaitu sebagai berikut:

Kingdom : Animalia

Filum : Echinodermata

Kelas : Holothuroidea

Ordo : : Aspidochirotida

Famili : Holothuridae

Genus : Holothuria

Spesies : Holothuria leucospilota (Brandt, 1835)

Teripang tali jangkar (Holothuria leucospilota) berwarna coklat dengan bintik-bintik hitam di bagian dorsal. Pada bagian ventral berwarna putih kekuningan. Teripang ini bila disentuh akan mengeluarkan getahnya berwarna putih memiliki kebiasaan berpegang pada batu karang mati, terutama pada bagian posteriornya, sedangkan pada bagian anteriornya sering menjulur pada permukaan pasir. Spesies ini hidup pada substrat padang lamun, batu berpasir dan terumbu karang.

\section{e. Bohadschia vitiensis}
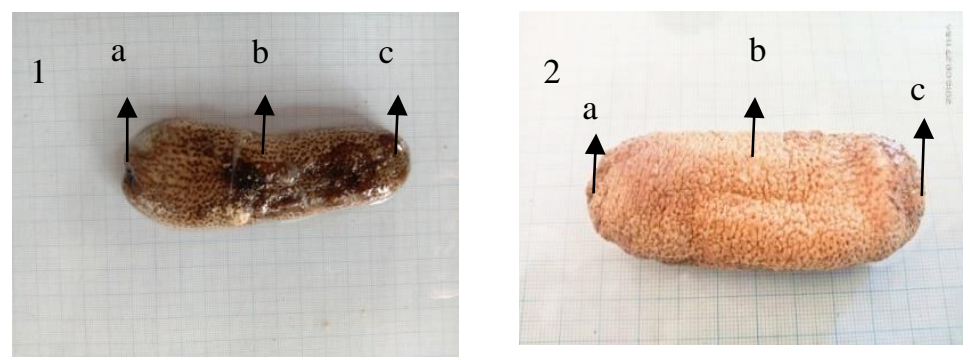

Gambar 6 Holothuria vitiensis 1. Dorsal: a. Celah mulut, b. spot, Celah anus. 2. Ventral: a. Posterior, b. Lekukan tubuh, c. Anteterior.

Bohadschia vitiensis memiliki bentuk tubung bulat memanjang, panjang tubuh $\pm 13 \mathrm{~cm}$ dan lebar \pm 5 $\mathrm{cm}$, serta warna tubuh coklat keputihan. Terdapat warna hitam di bagian dorsal dan bintik-bintik kecoklat, serta mulut berbentuk bulat, sedangkan pada bagian ventral berwarna putih. Hidup pada substrat berpasir dan pecahan karang serta di tumuhi padang lamun. 


\section{f. Bohadschia argus}
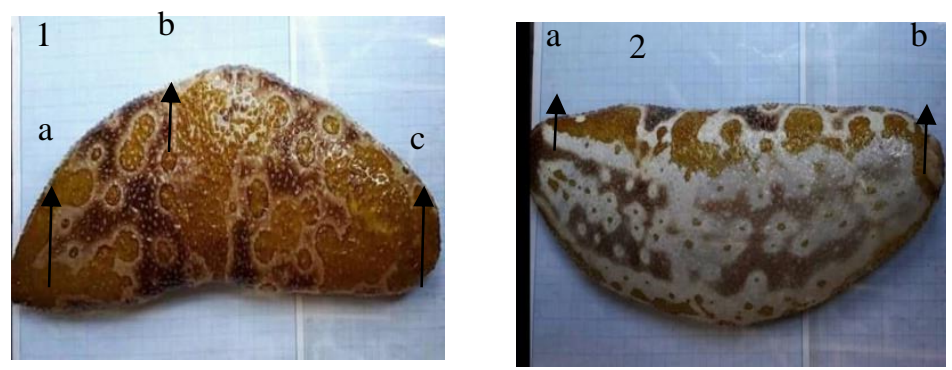

Gambar 7 Bohadschia argus: 1. Dorsal: a. Posterior, b. Bar primer, c. Anterior. 2. Ventral: a. Celah mulut, b. Celah anus.

Klasifikasi (pengelompokan) Bohadschia argus dalam sistem taksonomi yaitu sebagai berikut:

Kingdom: Animalia

Filum : Echinodermata

Kelas : Holothuroidea

Ordo : Aspidochirotida

Famili : Holothuridae

Genus : Bohadschia

Spesies : Bohadschia argus (Jaeger, 1833)

Bohadschia argus memiliki bentuk tubuh bulat memanjang dengan warna coklat kehitaman yang terdapat totol-totol krem berwarna coklat keputihan dan terdapat bintik-bintik kehitaman, panjang tubuh \pm 18 $\mathrm{cm}$ dan lebar $\pm 7 \mathrm{~cm}$, permukaan tubuh spesies ini kasar bila diraba. Hidup pada substrat berpasir dan berkarang serta ditumbuhi lamun.

g. Holothuria pervicax
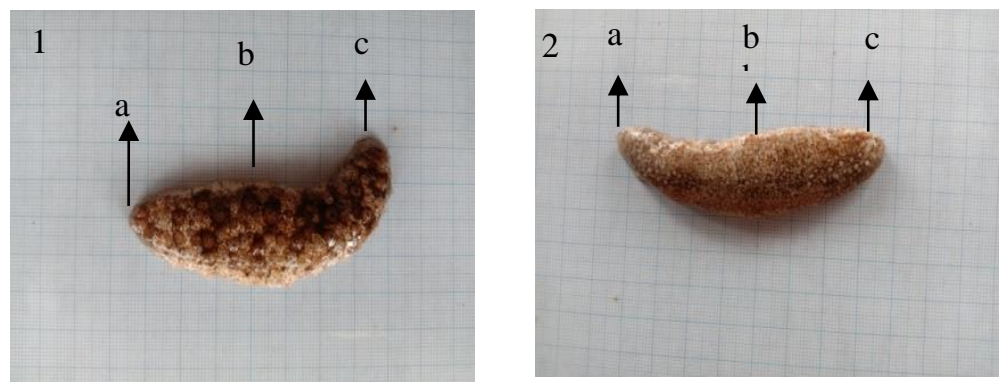

Gambar 8 Holothuria pervicax: 1. Dorsal: a. Celah mulut, b. Dot, c. Celah anus. 2. Ventral: a. Posterior, b. Spot, c. Anterior

Klasifikasi (pengelompokan) Holothuria pervicax dalam sistem taksonomi yaitu sebagai berikut:

Kingdom: Animalia

Filum : Echinodermata

Kelas : Holothuroidea

Ordo : Aspidochirotida

Famili : Holothuridae

Genus : Holothuria

Spesies : Holothuria pervicax (Jaeger, 1833)

Holothuria pervicax memiliki bentuk tubuh bulat memanjang dengan ujung yang agak meruncing. Pada bagian dorsal permukaan tubuhnya kasar berwarna putih kecoklatan dan terdapat bintik bintik berwarna coklat kehitaman yang tidak beraturan, bagian ventral permukaannya halus dan memiliki bintik-bintik 
berwarna putih kecoklatan. Panjang tubuh $\pm 8 \mathrm{~cm}$ dan lebar $\pm 3 \mathrm{~cm}$. Teripang ini hidup pada substrat pasir dan berkarang.

h. Holothuria sp. 1
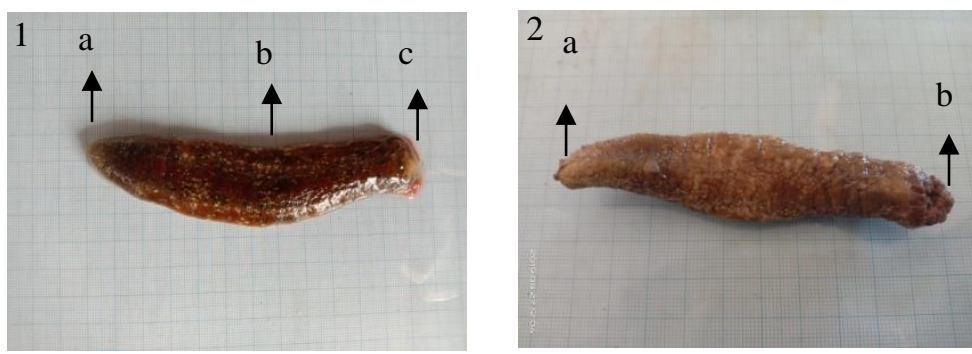

Gambar 9 Holothuria sp. 1: 1. Dorsal:a. Celah anus, b. Rambut halus, c. Celah mulut. 2. Ventral:a. Anterior, b. Posterior.

Klasifikasi (pengelompokan) Holothuria sp.,1 dalam sistem taksonomi yaitu sebagai berikut:

Kingdom: Animalia

Filum : Echinodermata

Kelas : Holothuroidea

Ordo : Aspidochirotida

Famili : Holothuridae

Genus : Holothuria

Spesies : Holothuria sp. 1 (Jaeger, 1833)

Holothuria sp.1 memiliki bentuk tubuh bulat memanjang, bagian dorsal berwarna merah kehitaman yang ditumbuhi rambut-rambut halus berwarna kecoklatan dan terdapat bintik-bintik berwarna hitam dan putih. .Pada bagian anterior meruncing dan posterior berbentuk bulat dan terdapat tentakel. Tubuh bagian vental berwarna merah bata. Teripang ini hidup pada substrat berkarang dan padang lamun.

i. Holothuria sp. 2
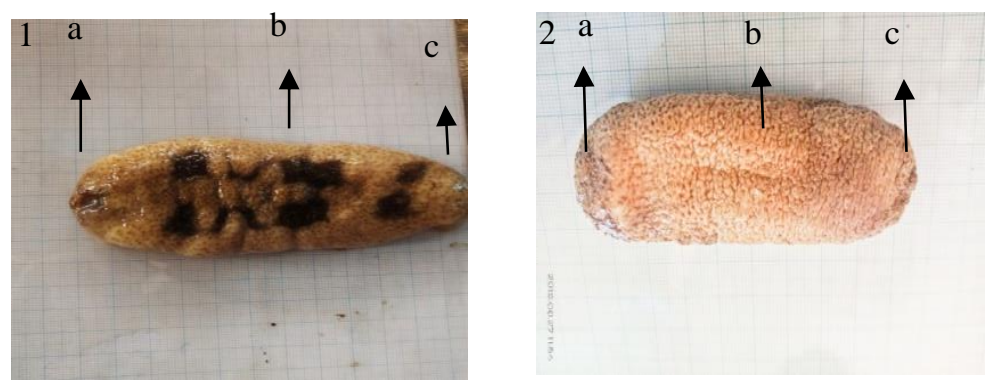

Gambar 10 Holothuria sp. 1: 1. Dorsal: a. Celah mulut, b. Dot, c. Celah anus2. Ventral: a. Posterior, b. Spot, c. Anterior

Klasifikasi(pengelompokan) Holothuria sp., dalam sistem taksonomi yaitu sebagai berikut:

Kingdom : Animalia

Filum : Echinodermata

Kelas : Holothuroidea

Ordo : : Aspidochirotida

Famili : Holothuridae

Genus : Holothuria

Spesies : Holothuria sp. 2 (Jaeger, 1833)

Holothuria sp. 2 berbentuk bulat memanjang atau silindris, panjang tubuh $\pm 13 \mathrm{~cm}$ dan lebar $\pm 6 \mathrm{~cm}$, bagian dorsal berwarna kuning keemasan dan terdapat warna hitam dengan bentuk yang khas berbentuk seperti kotak berjumlah lima pasang. Mulut berbentuk bulat dan tidak memiliki tentakel. Pada bagain ventral berwarna putih pucat dengan bintik-bintik berwarna hitam. Teripang ini hidup pada subtrat pasir dan pecahan karang yang ditumbuhi lamun. 

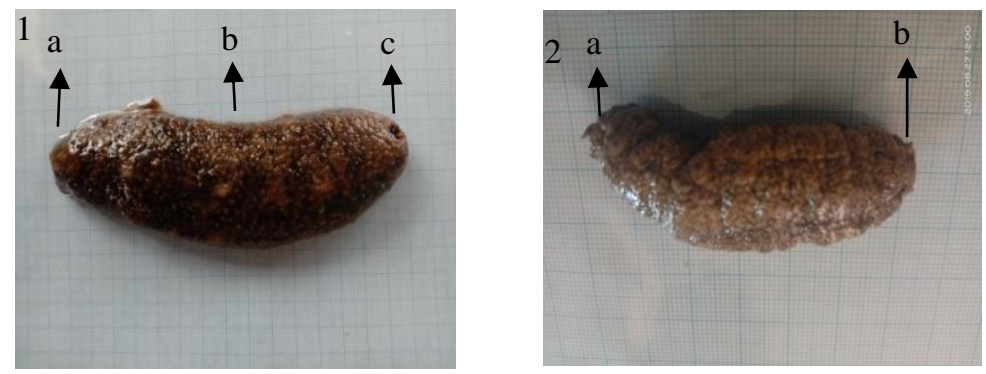

Gambar 11 Holothuria sp. 3: 1. Dorsal: a. Celah anus, b. Spot, c. Celah mulut. 2. Ventral : a. Anterior, b. Posterior

Klasifikasi (pengelompokan) Holothuria sp. 3 dalam sistem taksonomi yaitu sebagai berikut:

Kingdom: Animalia

Filum : Echinodermata

Kelas : Holothuroidea

Ordo : Aspidochirotida

Famili : Holothuridae

Genus : Holothuria

Spesies : Holothuria sp. 3

Holothuria sp. 3 memiliki bentuk tubuh bulat memanjang. Pada bagian dorsal berwarna coklat kehitaman, terdapat bintik-bintik hitam dan putih, permukaan tubuh kasar bila diraba, bagian dorsal memiliki permukaan halus berwarna coklat keputihan dan terdapat bintik-bintik berwarna coklat. Panjang tubuh \pm 15 $\mathrm{cm}$ dan lebar $\pm 6 \mathrm{~cm}$, mulut berbentuk bulat dan terdapat tentakel berukuran kecil. Teripang ini hidup di daerah pasir dan berkarang serta ditumbuhi lamun.

k. Holothuria sp. 4
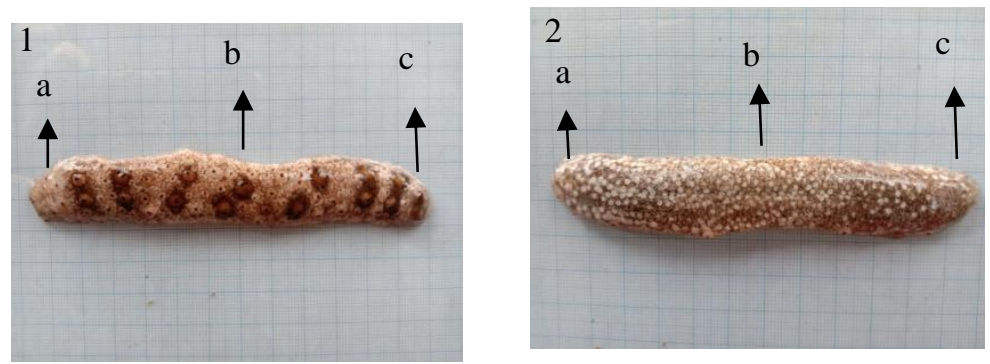

Gambar 12 Holothuria sp. 4: 1. Dorsal: a. Celah mulut, b. Dot, c. Celah anus. 2. Ventral: a. Posterior, b. Spot, c. Anterior.

Klasifikasi (pengelompokan) Holothuria sp. 4 dalam sistem taksonomi yaitu sebagai berikut:

Kingdom: Animalia

Filum : Echinodermata

Kelas : Holothuroidea

Ordo : Aspidochirotida

Famili : Holothuridae

Genus : Holothuria

Spesies : Holothuria sp. 4

Holothuria sp. 4 memiliki bentuk tubuh bulat memanjang, pada bagian dorsal berwarna putih kecoklatan dan terdapat bintik bintik hitam seperti bola mata berjumlah 7 pasang, bagian terdapat ventral berwarna putih dan terdapat bintik-bintik berwarna kecoklatan. Panjang tubuh $\pm 12 \mathrm{~cm}$ dan lebar $\pm 3 \mathrm{~cm}$, mulut berbentuk bulat terdapat tentakel berjumlah 14. Teripang ini hidup pada substrat pasir dan berlamun. 


\section{Holothuria sp. 5}
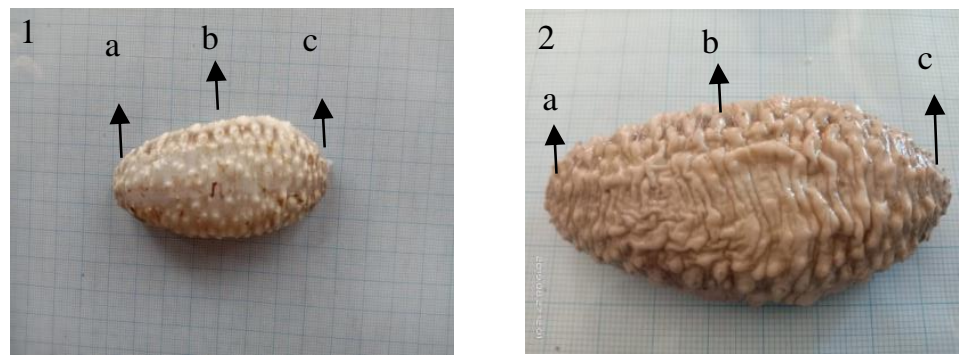

Gambar 13 Holothuria sp. 5: 1. Dorsal: a. Celah mulut, b. spot, c. Celah anus. 2. Ventral: a. Posterior, b. Lekukan tubuh, c. Anterior

Klasifikasi (pengelompokan) Holothuria sp. 5 dalam sistem taksonomi yaitu sebagai berikut:

Kingdom : Animalia

Filum : Echinodermata

Kelas : Holothuroidea

Ordo : : Aspidochirotida

Famili : Holothuridae

Genus : Holothuria

Spesies : Holothuria sp. 5

Holothuria sp. memiliki bentuk tubuh bulat oval, panjang tubuh $\pm 8 \mathrm{~cm}$ dan lebar tubuh $\pm 4 \mathrm{~cm}$. Pada bagian dorsal berwarna putih kecoklatan dengan bintik-bintik di seluruh tubuh, sedangkan bagian ventral berwarna putih pucat dan terdapat lekukan tubuh. Teripang ini hidup di daerah berpasir dan pecahan karang serta ditumbuhi padang lamun.

\subsection{Pembahasan}

Berdasarkan hasil penelitian yang telah dilakukuan di zona intertidal Pulau Ottouwe Kabupaten Wakatobi, ditemukan 12 jenis teripang dengan substrat berpasir, pecahan terumbuh karang dan padang lamun. Kedua belas jenis teripang tersebut yaitu Holothuria scabra, Holothuria atra, Holothuria fuscocinerea, Holothuria leucospita, Holothuria pervicax, Bohadschia argus, Bohadschia vitiensis, Holothuria sp. 1, Holothuria sp. 2, Holothuria sp.3, Holothuria sp. 4, Holothuria sp. 5.

Teripang pasir (Holothuria scabra) merupakan spesies yang terbanyak ditemukan pada kedua stasiun yaitu stasiun I ditemukan sebanyak 7 spesies dan stasiun 2 sebanyak 8 spesies. Jumlah keseluruhan adalah 15 spesies. Teripang pasir (Holothuria scabra) memiliki tubuh bulat memanjang. Bagian dorsal berwarna abuabu sampai kehitaman dengan garis melintang dan antara garis-garis tersebut terdapat warna putih. Warna pada bagian ventral kuning keputihan dengan bercak-bercak kecil. Seluruh permukaan kulitnya kasar jika diraba. Spesies ini banyak ditemukan pada subtrat berpasir dan berlamun dengan suhu $23-26^{\circ} \mathrm{C}$ dan hidup pada $\mathrm{pH}$ air laut 6-7.

Menurut Marcelien dkk (2015), teripang pasir (Holothuria scabra) mempunyai bentuk badan yang bulat, warna punggungnya abu-abu sampai agak kehitaman dengan garis melintang dan di antara garis-garis itu terdapat warna putih. Warna bagian perutnya kuning keputihan dengan bercak-bercak hitam kecil. Seluruh permukaan kulitnya kasar bila diraba. Jenis teripang ini hidup sendiri antara karang dan perairan yang substrat pasir halus serta ditumbuhi tumbuhan laut (rumput laut). Teripang pasir banyak ditemukan di sela-sela karang yang masih hidup ataupun mati dan di perairan yang dasarnya mengandung pasir yang halus (Joko Martoyo, dkk 2006).

Teripang hitam atau keling (Holothuria atra) merupakan urutan kedua yang terbanyak ditemukan pada kedua stasiun yaitu pada stasiun I ditemukan sebanyak 5 spesies dan stasiun II ditemukan sebanyak 6 spesies. Jumlah keseluruhan yaitu 13 spesies. Spesies tersebut banyak ditemukan pada substrat berpasir dan berlamun. Menurut Purwati (2008) Holothuria atra dikenal sebagai teripang darah karena cairan kemerahan yang dimilikinya jika permukaan tubuhnya digosok. Holothuria atra menyukai tempat terbuka di tempat yang selalu tergenang pada pasang surut yang biasanya memiliki daerah bersubstrat keras dan kasar. 
Menurut Massin (1996), Holothuria atra memiliki bentuk tubuh yang silindris dengan panjang 15-30 $\mathrm{cm}$. Warna tubuh hitam keseluruhan baik dorsal maupun ventral. Papila dan kaki tabung tersebar tidak beraturan. Mulut terletak di ujung anterior bagian ventral dengan tentakel berbentuk perisai (paltate) berjumlah 20. Anus berada di ujung posterior. Tipe spikula pada bagian dorsal yaitu table dan rosettes, pada bagian ventral yaitu pseudo-plates, sedangkan untuk tentakel tidak terdapat spikula.

Spesies ini hidup pada suhu $23-24^{\circ} \mathrm{C}$ dan $\mathrm{pH}$ (keasaman) peraiaran adalah 7. Menurut Sutaman (1993), bahwa suhu yang baik untuk kehidupan teripang berkisar antara $22-32{ }^{\circ} \mathrm{C}$. Menurut Radisho (1994), bahwa pH yang baik untuk kehidupan teripang keling (Holothuria atra) adalah berkisar antara 6,5- 8 .

Holothuria fuscocinerea dan Holothuria leucospilota merupakan dua spesies yang memiliki jumlah yang sama ditemukan di lokasi penelitian. Kedua spesie ini menempati urutan ketiga yang terbanyak ditemukan pada kedua stasiun yaitu pada stasiun I ditemukan sebanyak 6 spesies dan stasiun II ditemukan sebanyak 6 spesies. Jumlah keseluruhan yaitu 12 spesies. Menurut Massin (1999), Holothuria fuscocinerea memiliki ciri morfologi tubuh bulat memanjang dengan warna dasar tubuh cokelat tua dengan garis besar tebal melintang di tubuh dari ujung anterior hingga posterior yang hanya terdapat di bagian dorsal tubuh. Tekstur kulit lembut, lunak dan dinding tubuh yang sedikit tebal.

Spesies ini banyak ditemukan pada substrat berpasir, berkarang dan berlamun dengan suhu $23-26{ }^{\circ} \mathrm{C}$ dan hidup pada $\mathrm{pH}$ (keasaman) peraiaran adalah 6-7. Menurut Yusron (2001), teripang hidup pada daerah tutupan karang. Menurut Kordi (2010), pH yang baik untuk kehidupan teripang adalah adalah pH 6,5-8.

Holothuria leucospilota juga merupakan urutan ketiga yang terbanyak ditemukan pada kedua stasiun yaitu pada stasiun I ditemukan sebanyak 5 spesies dan stasiun II ditemukan sebanyak 7 spesies. Jumlah keseluruhan yaitu 12 spesies. Teripang tali jangkar (Holothuria leucospilota) berwarna coklat dengan bintikbintik hitam di bagian ventral. Di bagian ventral berwarna coklat pucat. Teripang keling atau teripang getah (Holothuria leucospilota) atau yang dulu dikenal dengan nama latin Holothuria vagabunda memiliki ciri morfologis yang menonjol yaitu bentuk badan silindris memanjang berwarna hitam, tubuhnya lembut, lentur, dan ditutupi dengan papilla lembut, apabila dalam keadaan kontraksi berbentuk buah pir, tegumen lunak, dan memiliki tabung cuvierian (Conand, 1998 dalam Hana, 2011).

Spesies ini banyak ditemukan pada subtrat berpasir, berkarang dan berlamun dengan suhu $23-26{ }^{\circ} \mathrm{C}$ dan hidup pada pH (keasaman) peraiaran adalah 6-7. Menurut Gultom (2004), Teripang biasanya hidup di daerah berpasir yang bercampur pecahan karang dan banyak ditumbuhi tumbuhan laut atau lamun. Menurut Lewerissa (2009), kisaran suhu yang baik untuk pertumbuhan teripang adalah $27-30^{\circ} \mathrm{C}$. Menurut Wibowo dkk (1997), dimana nilai $\mathrm{pH}$ yang baik adalah $6,5-8,5$,

Bohadschia vitiensis merupakan urutan keempat yang terbanyak ditemukan pada kedua stasiun yaitu pada stasiun I ditemukan sebanyak 6 spesies dan stasiun II ditemukan sebanyak 5 spesies. Jumlah keseluruhan yaitu 11 spesies. Spesies tersebut banyak ditemukan pada subtrat berpasir, berkarang dan berlamun dengan suhu $23-26{ }^{\circ} \mathrm{C}$ dan hidup pada $\mathrm{pH}$ (keasaman) peraiaran adalah 6-7. Menurut Massin (1996), spesies ini memiliki bentuk tubuh bulat memanjang dengan panjang 11-15 cm. Warna pada bagian dorsal yaitu coklat dengan motif hitam khas, sedangkan pada bagian ventral berwarna putih.

Bohadschia argus merupakan urutan kelima yang terbanyak ditemukan pada kedua stasiun yaitu pada stasiun I ditemukan sebanyak 4 spesies dan stasiun II ditemukan sebanyak 5 spesies. Jumlah keseluruhan yaitu 9 spesies. Spesies tersebut banyak ditemukan pada subtrat berpasir, berkarang dan berlamun dengan suhu 23$26^{\circ} \mathrm{C}$ dan hidup pada $\mathrm{pH}$ (keasaman) perairan 6-7.Bohadschia argus memiliki bentuk tubuh bulat memanjang dengan warna coklat kehitaman yang terdapat totol-totol krem berwarna coklat keputihan, ukuran panjang tubuh $18 \mathrm{~cm}$ dan lebar $7 \mathrm{~cm}$, serta permukaan tubuh yang kasar. Hidup di dasar peraiaran karang berpasir.

Holothuria pervicax merupakan urutan keenam yang terbanyak ditemukan pada kedua stasiun yaitu pada stasiun I ditemukan sebanyak 3 spesies dan stasiun II ditemukan sebanyak 4 spesies. Jumlah keseluruhan yaitu 7 spesies. Spesies tersebut banyak ditemukan pada substrat berpasir, berkarang dan berlamun dengan suhu $23-26{ }^{\circ} \mathrm{C}$ dan hidup pada $\mathrm{pH}$ (keasaman) peraiaran adalah 6-7. Holothuria pervicax memiliki bentuk tubuh bulat memanjang dengan ujung yang agak meruncing, pada bagian ventral permukaan tubuhnya kasar berwarna putih kecoklatan, terdapat spot berwarna coklat kehitaman yang tidak beraturan, bagian dorsal permukaannya halus, berwarna putih kecoklatan. Ukuran panjang tubuh $8 \mathrm{~cm}$ dan lebar $3 \mathrm{~cm}$. Hidup pada subtrat pasir, dan berkarang. 
Holothuria sp. 1 merupakan urutan ketujuh yang terbanyak ditemukan pada kedua stasiun yaitu pada stasiun I ditemukan sebanyak 4 spesies dan stasiun II ditemukan sebanyak 2 spesies. Jumlah keseluruhan yaitu 6 spesies. Spesies tersebut banyak ditemukan pada subtrat berpasir, berkarang dan berlamun dengan suhu 23 $26{ }^{\circ} \mathrm{C}$ dan hidup pada $\mathrm{pH}$ (keasaman) peraiaran adalah 6-7. Holothuria sp. 1 memiliki bentuk tubuh bulat memanjang, bagian ventral berwana merah merah kehitaman yang di tumbuhi rambut-rambut halus, bagiaan dorsal berwarna merah bata serta terdapat spot. Pada bagian anterior meruncing dan tubuh bagian posterior berbentuk bulat. Pada bagian posterior terdapat tentakel berjumlah 18. Hidup pada subtrat berkarang dan padang lamun

Holothuria sp. 2 merupakan urutan ketujuh yang terbanyak ditemukan pada kedua stasiun yaitu pada stasiun I ditemukan sebanyak 3 spesies dan stasiun II ditemukan sebanyak 3 spesies. Jumlah keseluruhan yaitu 6 spesies. Spesies tersebut banyak ditemukan pada subtrat berpasir, berkarang dan berlamun dengan suhu 23$26^{\circ} \mathrm{C}$ dan hidup pada $\mathrm{pH}$ (keasaman) peraiaran adalah 6-7. Holothuria sp. 2 berbentuk seperti bulat memanjang, tubuh berwarna kuning keputihan, panjang tubuh $13 \mathrm{~cm}$ dan lebar $6 \mathrm{~cm}$, bagian vental terdapat 7 pasang bar sekunder dan spot serta Mulut berbentuk bulat dan tidak memiliki tentakel. Hidup pada subtrat berpasir dan padang lamun.

Holothuria sp. 3. merupakan urutan ketujuh yang terbanyak ditemukan pada kedua stasiun yaitu pada stasiun I ditemukan sebanyak 2 spesies dan stasiun II ditemukan sebanyak 4 spesies. Jumlah keseluruhan yaitu 6 spesies. Spesies tersebut banyak ditemukan pada subtrat berpasir, berkarang dan berlamun dengan suhu 23$26{ }^{\circ} \mathrm{C}$ dan hidup pada $\mathrm{pH}$ (keasaman) peraiaran adalah 6-7. Holothuria sp.3 memiliki bentuk tubuh bulat memanjang, warna tubuh coklat kehitaman, bagian ventral terdapat bintik-bintik, permukaan tubuh kasar, bagian dorsal memiliki permukaan halus dan terdapat spot di seluruh tubuhnya. Ukuran panjang tubuhnya 15 $\mathrm{cm}$ dan lebar $6 \mathrm{~cm}$, mulut berbentuk bulat dan terdapat tentakel berukuran kecil. Hidup pada subtrat pasir dan berkarang.

Holothuria sp. 4 merupakan urutan kedelapan yang banyak ditemukan pada kedua stasiun yaitu pada stasiun I ditemukan sebanyak 1 spesies dan stasiun II ditemukan sebanyak 2 spesies. Jumlah keseluruhan yaitu 3 spesies. Spesies tersebut banyak ditemukan pada subtrat berpasir, berkarang dan berlamun dengan suhu 23$26{ }^{\circ} \mathrm{C}$ dan hidup pada $\mathrm{pH}$ (keasaman) peraiaran adalah 6-7. Holothuria sp. 4 memiliki bentuk tubuh bulat memanjang, warna tubuh putih kecoklatan, bagian ventral dan dorsal terdapat dot, panjang tubuh $12 \mathrm{~cm}$ dan lebar $3 \mathrm{~cm}$, mulut berbentuk bulat terdapat tentakel berjumlah 14. Hidup pada subtrat berkarang dan padang lamun

Holothuria sp. 5 merupakan urutan kesembilan yang banyak ditemukan pada kedua stasiun yaitu pada stasiun I ditemukan sebanyak 1 spesies dan stasiun II ditemukan sebanyak 1 spesies. Jumlah keseluruhan yaitu 2 spesies. Spesies tersebut banyak ditemukan pada subtrat berpasir, berkarang dan berlamun dengan suhu 23 $26^{\circ} \mathrm{C}$ dan hidup pada pH (keasaman) peraiaran adalah 6-7. Holothuria sp. 5 memiliki bentuk tubuh bulat oval, warna tubuh putih dan kecoklatan, terdapat dot di permukaan tubuh, pada bagian anterior dan posterior meruncing. Panjang tubuh $8 \mathrm{~cm}$ dan lebar $4 \mathrm{~cm}$. Teripang ini hidup pada subtrat pasir dan karang serta ditumbuhi lamun.

\section{KESIMPULAN}

Berdasarkan hasil penelitian yang telah dilakukan di zona intertidal Pulau Ottouwe maka dapat disimpulkan bahwa pada lokasi tersebut ditemukan 12 spsies dari 60 spesies yang ada di Indonesia. Teripang tersebut dari 1 famili yang terdapat pada titik pengamatan (garis transek) yaitu Holothuroidea yaitu Holothuria scabra, Holothuria atra, Holothuria fuscocinerea, Holothuria leucospilota, Holothuria pervicax, Holothuria sp.1, Holothuria sp.2, Holothuria sp.3, Holothuria sp.4, Holothuria sp.5, Bohadschia marmorata, bohadschia argus.

\section{DAFTAR PUSTAKA}

Dahuri, Rokhmin. 2003. Keanekaragaman Hayati Laut. Jakarta: Gramedia Pustaka Utama.

Didi. S.,Sarmin. T.,dkk.2015. Pedoman UmumIdentifikasi dan Monitoring Teripang. Penerbit: Jakarta.

Effendi, H. 2003. Telaah Kualitas Air Bagi Pengelolahan Sumber Daya Lingkungan Perairan. Penerbit Kansius. Yogyakarta. 
https://jurnal.unsulbar.ac.id/index.php/saintifik

Gultom, C. P. W. 2004. Laju Pertumbuhan Dan Beberapa Aspek Bio-Ekologi Teripang Pasir (Holothuria scabra) Dalam Kolam Pembesaran Di Laut Pulau Kongsi, Kepulauan Seribu, Jakarta Utara. Program Studi Ilmu Kelautan IPB, Bogor

Ikhsan. N., 2015. Distribusi Teripang Di Daerah Padang Lamun Pulau Wanci Sulawesi Tenggara. Sekolah Pascasarjana. Institut Pertanian Bogor. Bogor.

Kordi, M. G. 2010. A to Z Budidaya Biota Akuatik Untuk Pangan, Kosmetik dan Obat-obatan . Andi Offset Yogyakarta.

Lewerissa, Y. A.2009. Pengolaha Teripang Berbasis Sasi di Negeri Porto dan Desa Wariuala Provinsi Maluku. Sekolah Pascaarjana Institute Pertanian Bogor. Bogor

Macelien, dkk. 2015. Keanekaragaman Timun Laut (Ecinodermata: Holothuroidea) di Perairan Sabu Raijua, Pulau Sabu, Nusa Tenggara Timur. Fakultas Keguruan dan Perikanan. Undana. Kupang.

Martoyo, J. N. Aji dan T. Winanto. 2006. Budidaya Teripang. Penebar Swadaya. Jakarta. 75pp.

Massin C. 1996. Results of the Rumphius Biohistorical Expedition to Ambon (1990). Part 4. The Holothuroidea (Ecinodermata) colectet during the Rumphius Biohistorical Expedition.Zool Verh. 307: 153.

Purwati, P. 2008. Timun Laut Lombok Barat. Jakarta: Ikatan Sarjana Osenologi Indonesia (ISOI).

Satria. A. G. G.,dkk.. 2014. Kelimpahan Jenis Teripang di Perairan Terbuka dan Perairan Terturtup Pulau Panjang Jepara Jawa Tengah.Journal OfMaquares.Vol.3(1).108-115.

Sutaman, 1993. Petunjuk Praktis Budidaya Teripang. Yogyakarta: Kanisius.

Wibowo, S. dkk. 1997. Teknologi Penanganan dan Pengolahan Teripang (Holothuroidea). Jakarta: IPPL Slipi.

Yusron, E. 2006. Biodiversitas Ecinodermata Di Perairan Pantai Takofi, Pulau. Moti Maluku Utara. Makara Sains 10(1):41-46 